vation upheaved by volcanic action. This view does not appear to be sustained by those internal rocky formations which characterize the mountain ranges and volcanic elevations of Mexico. The material of which it is composed is represented to be an admixture of clay, sand and gravel, resembling in this particular the mounds of the Mississippi, which are known to be devoid of those stratifications which pervade the natural formations of the earth.

[To be continued.]

\title{
SKETCHES OF HISTORY AND INCIDENTS CONNECTED WITH THE SETTLEMENT OF WAPELLO COUNTY, FRON 1843 TO 1859, INCLUSIVE.
}

BY G. D. R. BOYD, OTTOMWA.

[Continued from page 44.]

OVERMAN AND PRITCHETT CASE.

Abner'Overman, an old man living in the north-western part of the county, entered a tract of land that had formerly been claimed by Bird Pritchett, who is also still a resident of this county. This was in March, 1849. The matter was immediately brought before the club of that vicinity by Pritchett. They met, and in hot haste waited upon Overman en masse. Their spokesman communicated the object of their visit, which was to persuade or extort a deed from Overman and his wife to Pritchett for the land in question, and for this purpose the mob had secured the services of a magistrate-a conservator of the peace (?)-one Esquire Colés, to take the acknowledgment of Overman and his wife to their transfer of the property. Overman was urged to accede to the propositions of the mob, but he steadily persisted in refusing to make any concessions whatever. Other appliances were then resorted to. A "ducking" in the river was threatened. Overman was still obstinate. He was then seized upon and led towards the river, which was convenient, when the frantic cries of Mrs. Overman caused him to hesitate, and finally he reluctantly and unwillingly assented. How far he was aided 
in arriving at this conclusion by his threatened immersion is not known ; but we are under the conviction that the old man was "game," and had it not been for the frenzied state of his family, would have "soaked" for some time before yielding to the demands of the mob. He was placed upon a horse and taken to Eddy ville, where a deed was drawn up and signed, sealed and delivered by Overman; but, as the sequel will show, this acquiescence of Overman was only a matter of policy - a matter of personal safety for the time being. Deeming himself outraged, he determined that the case should not end there, but that in due time he would seek redress from the proper source. Accordingly, a suit was commenced some time after against Pritchett and others for damages, and to set aside the deed. This suit occupied some two days. Cyrus Olney was then on the bench. The testimony was in accordance with the foregoing statement of facts. During the pendency of the case, Coles, the justice of the peace who had taken the acknowledgment of the deed, was placed upon the stand, and while there, the Judge incensed at the manner in which he had violated his oath of office and became an aider and abettor in lawless violence, ordered him to be taken into custody, and his case being presented to the grand jury, an indictment was found against him for his action at the time the deed was procured from Overman. Judge Olney's charge to the jury in this case, was long, labored, learned and eloquent. The violated majesty of the law was fully vindicated, and a wholesome rebuke administered to all those who had infringed upon its prerogatives, or had violated its' expressed authority. The case having been appealed, the Supreme Court speak of Olney's charge as follows: "But it is claimed that the instructions are argumentative and calculated to mislead the jury. To this objection it must be conceded that the charge is long, earnest and eloquent; that it describes the wrongs claimed to have been proved in impressive, forcible and perspicuous terms, and it tells the jury with all the ardor of incensed Justice that if these wrongs were perpetrated, how repugnant they are to 17 
the law of the Iand; how unjustifiable they were even if sanctioned by any self-constituted unauthorized combination of men, and how repulsive to the peace of society, to the quiet and harmony of the domestic circle, and to the natural and legal rights of citizens." The charge is there characterized as "unusually impressive and labored," and concludes that "if the plaintiff sncceeded in establishing the material facts which he claimed to have proved, the condition of the country, the prejudiced state of society, and the depraving influence which the prevalence of mob law may have had upon the minds of the jurors, might well justify the bold position and fervent expressions of the Court as an exponent of the law, as an administrator of justice, and as a conservator of the peace." Considering the period, the state of public feeling, and the short space of time in which it was prepared, it is truly an able production, brought forth upon the spur of the moment, and abounding in manly positions in favor of law and order, and the rights of individuals against the insults and inflictions of mob violence. Both as a legal and a literary production it is of more than ordinary merit, and as an important part of the history of the times of which we write, we regret that for want of room, we are not enabled to publish it entire, in connection with these sketches, for perusual by those to whom it is at present inaccessible. We make the following extract: "How much would be a compensation for bodily pain, and for fright and fear, and for wounded feelings from personal indignities, and for anxiety and inquietude for a confused and screaming family, and for temporary loss of liberty, and for wounded pride and feeling of disgrace, and for being held in duress by force and fear, while one's home is being desecrated and his wife ontraged, and her rights wrested from her? How much would be a compensation for these injuries, if any of them were inflicted on the plaintiff, is for you to decide, by your own good sense and judgment. For all such injuries the redress should be ample, for money is a poor return at best." The jury returned a verdict of guilty, damages $\$ 150$. Overman also succeeded in having the deed set aside. This was aftirmed by the Suprome Court. 
SHOOTING AFFAIR OF ROSS AND WRIGHT.

The immediate cause that led to the unfortunate and fatal encounter of Joseph R. Ross and Dr. Geo. M. Wright, which took place in Ottumwa, at the public land sales, on the 5th of June, 1849, was about a land claim; and the painful and melancholy result of this difficulty but too truly illustrates the wild, reckless and blood-thirsty spirit that pervaded the community, and which was the natural offspring of the prevalency of mob organizations and the reign of Lynch-law. A bad state of feeling had existed between the parties for some months previous, and Wright had formed the resolution of bidding on the land claimed by Ross on the south side of the Des Moines, opposite Otturmwa. Accordingly, when the land was offered for sale, Ross bid the customary price, $\$ 1,25$ per acre, and Wright immediately bid $\$ 1,50$. Ross was heard to say, "D-n you, you will never bid again," and simultaneously both parties drew their pistols and advanced. It was generally considered that both fired about the same time, although the by-standers, which were numerous, were much divided in opinion upon this point. Ross received a shot in the jaw, entering at the mouth and passing out at the angle of the jaw, and a cut on the back part of his head. Dr. Wright received two wounds, one in the left arm and the other in the side, the ball entering at the fifth rib. This latter wound proved mortal, and after lingering in a state of unconsciousness some five hours, the doctor died. Ross recovered, and was subsequently tried for the murder of Wright. A change of venue was taken to the Albia District Court, at which place, in November, 1849, he was acquitted. This melancholy tragedy created great excitement. Both parties had their friends, and a feeling of bitter hostility was engendered thronghout the community, which continued to be manifested for several years. We close this branch of our subject by copying, verbatim, the proceedings of a claim meeting held in Green township, Feb. 18th, 1857. There is no scarcity of fights, and broils, and bloody encounters, occasioned by the operations of these "club laws," in the early history of the 
county. The incidents related are deemed sufficient, however, to give the reader a tolerable idea of the state of affairs during the time that the mob spirit was prevalent in this part of the country. The following is about the last meeting of this character that was held in the county:-

"We, the undersigned citizens of Green township, Wapello county, Iowa, met at Benj. Baum's, in said township, on the 18th February, for the purpose of taking into consideration the case of Geo. W. Kendrick for entering Gabriel Higdon's land claim, and chose three committee men, viz., Benj. Baum, Jos. H. Glover and Benj. Reed, who offered the following propusals to the said Kendrick, to wit, fifty-two dollars and fifty cents was offered to said Kendrick, and he refused it. Then they offered to take one-half of the land and pay him $\$ 26,25$. He also refused, and said he would enter into no compromise whatever; he would die first, and so said his mother, father, brother-in-law and Harts, his uncles. Then the committee returned to the crowd, and the following resolutions were passed :-

"Resolved, That we will disown the Kendrick family and the Hart family, as neighbors, until the said Kendrick comes forward and makes a compromise with the said Higdon for said land.

"Resolved, That the proceedings of this meeting be published in the Des Moines Republic and Courier." This was signed by twenty-eight persons and published.

The penalty in this case, it will be seen, was very mild, when compared with the cases before mentioned, and exhibits the fact that violent and forcible measures at this time had become unpopular, and consequently were relinquished. The citizens of Green seemed content with expressing their contempt for such a dishonorable act, and resolved to treat the offender, his aiders and abettors accordingly.

The first regular election was held in the county in August, 1844. John C. Evans, James B. Wright, and John B. Gray were chosen Commissioners; Joseph Hayne, Sheriff; and Chas. Overman, Co. Comms. Clerk. 
During the year 1845 a charter was granted to the Appanoose Rapids Dam and Milling Company ; a contract entered into for the building of a jail at Uttumwa; the name of Louisville changed to that of Ottumwa.

As before stated, during a period of several years, but few events of public importance transpired worthy of record in the history of the county. A well connected train of statistical information during this period is also wanting. While the County Commissioner's books are copiously filled with allowances, appropriations. locations of roads and licenses for dram shops, we look in vain for a single exhibit of the financial condition of the county, or a scrap of information relative to the population, or wealth of its inhabitants. Such an unintelligible and nnsatisfactory condition of county records would constitute, in our opinion, a very plausible reason for abolishing that system of county government:

In 1848 , the pioneer newspaper, the "Des Moines'Courier," was started at Ottumwa, by J. H. D. Street and R. H. Warden. With but little intermission, it has been published from Angust of that year to the present time. During that year some twenty flat-bottomed boats were loaded at Eddyville and Ottumwa with grain and floated down the river to find a market; the Des Moines River Improvement was put nnder contract to Ottumwa; $6,026,174$ acres of land were entered in the county; 1,190 votes cast at the general election in August; the Sons of Temperance organized throughont the county in November, and on the 23th of the same month the officers of the Masonic Lodge at Ottumwa were installed; coaches commenced running three times a week through the county during the fall; the office of the Board of Public

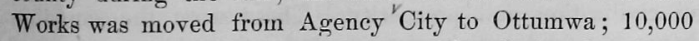
hogs were driven from the county to market during the winter.

\section{9.}

Assessed value of property, $\$ 882,422$. The receipts of the county this year above liabilities was $\$ 2,052.06$. Whole number of votes cast at the general election, 1,222. A bridge meeting was held at Eddyville, Feb. 9th, for the purpose of 
taking preliminary steps towards building a bridge across the Des Moines at that point; name of Sac and For Agency changed by the P. O. Department to Agency City, in June.

The navigation, by steamer, of the Des Moines river, as far up as Wapello county, was limited to one or two expeditions, prior to 1849. On the 4th of April of that year, the steamboat' Revenue Cutter passed as far up as Eddyville. She was followed soon after by the steaner Dove and Pearl, one of which traversed the river to Des Moines City (then Raccoon Forks). Since that time boats have plied regularly during the Spring and Summer months of every year, between Keokuk and Des Moines City, while at this time the little steamer Charles Rogers, makes regular trips to Fort Dódge, 100 miles further up the Des Moines. The facilities which the river this affiords the pcople of this county for importation and the exportation of their surplus products, has ever been considered by them as a great natural advantage, tending to increase their population and wealth, develop the resources of the county, and ultimately make it a wealthy agricultural, commercial and manufacturing district. And entertaining these flattering hopes of future greatness and prosperity, they have erer watched with jealous care every project that promised to facilitate the navigation of the noble stream that traverses their county. The liberal donation made by the general Government towards improving the river, was duly appreciated, and the people looked forward to an early day when by slack water narigation steamers could penetrate their borders any month in the year, when mills and manufactories would be erected at these dams, and the country would rapidly merge from a comparative wilderness to the highest stage of civilization and prosperity. These were the sanguine hopes, the fond anticipations, and the flattering prospects of our people, and although doomed to disappointment, they very reasonably and properly entertained these expectations. After years had elapsed, however, in fruitless anxiety in regard to the river improvement-witnessing year after year the donation frittering away, and the work scarcely commenced, 
their high wronght hopes were naturally relinquished, after which they looked about for other facilitis of communication with our Mississippi neighbors. The l:istory of the Des? Moines river improvement is known to tho people of the valley as a mammoth failure, and although intimately connected a with the history of our county, it would be considered a work of supererogatiou to attempt a detailed account of its operations. It was certainly an outrageous inisapplication and perversion of the people's money-a peculating, monopolizing, hydra-headed institution-squandering the best lands in the State, and deceiving, disappointing and blasting the hopes of the people of the whole valley. It was a miscarriage of a public nature of a magnitude and importance, that has no parallel for recklessness and enormity in the history of our conntry. It was finally demonstrated that the project not only did not promise to effect any permanent improvement of the navigation of the river, but the few dams attempted to be constructed for the purpose of drawing the money from the treasury, presented obstructions and impediments to its navigation that would not otherwise have been felt. Accordingly, the people of Wapello connty held a public meeting at Ottumwa, on the $23 \mathrm{~d}$ day of November, 1850 , to adopt measures to remove dams and other obstructions from the Des Hoines river. This meeting was called as follows:-

"The undersigned, citizens of Wapello county, believing that the artificial and illegal obstructions to the navigation of the Des Moines river can no longer be tolerated, we have determined to take such legal and rightful measures as will fully and effectually remove this enormous public grievance. We therefore invite all of our fellow-citizens to meet us in convention at Ottumwa, on Saturday, the $23 \mathrm{~d}$ inst., to consult on the necessary measures to effect the contemplated object." This was signed by sixty citizens of the county.

At the meeting thus called on the $23 \mathrm{~d}$, which was very largely attended, the following proceedings were had:"The meeting was called to order by W. Biggs, Esq., on whose motion J. W. Hedrick, Esq., of Dahlonega township, 
was elected president of the meeting, and W. A. Thompson, Esq., secretary. The object of the meeting was then stated at length by James Baker, on whose motion a committee of five was appointed to draft resolutions expressive of the sense of this meeting. J. Baker, W. Biggs, P. C. Jeffries, J. W. Norris, and J. M. Péck were appointed as said committee, after which various means were proposed and discussed for the purpose of effecting the object in contemplation, by Messrs. Baker, Biggs, Caldwell, Norris and Dugger.

"The committee on resolutions, atter having retired a short time, appeared in convention and submitted the following report, which was unanimously adopted:

"Whereas, the obstructions by the old dams in the Des Moines river, to its navigation, are a public grievance which the growing interest of this great valley can no longer submit to without great detriment to the inhabitants; and whereas, the vast resources of the valley require that the improvement should be completed at an early day. Therefore,

Resolved, That in the opinion of this meeting the next session of the legislature should provide for removing the obstructions to the navigation of the Des Moines river, occasioned by the old dams, by the time of the opening of navigation the ensuing spring, and also authorize the Board of Public Works to provide slopes to pass the down steamboats over such (if any) of the new dams as may be in a condition to obstruct the navigation.

"Resolved, That it is the duty of the legislature to adopt some plan by which the lands included in the grant can be used to facilitate the improvement of the river by anticipating the sale of the lands, by hypothecation or selling them to responsible companies or individuals for the completion of the work.

"Resolved, That the public sentiment of this valley requires the redress of this public grievance, and looks to the next legislature as the proper source of relief, and demand of their Representatives prompt and efficient action.

"W. A. Thompson, Sec'y."

"J. W. Hedrick, Pres't. 
It will be seen that not only the "old dams" were considered as obstructions, but that the new dams were augmenting these obstructions to navigation. Relief was therefore sought of the legislature. These new dams have been a serious impediment to navigation from that time to the present, and they still remain as monuments of the wildest and most reckless folly, of misapplied and squandered thousands-relics of stupendous tomfoolery. But it is now too late to animadvert upon this subject. The time has passed when such discussion would tend to effect any good. But it may not be amiss that occasionally this subject should be referred to by the peoplethat it should be treasured up in their history as a beacon light, warning them to give a wide bifth in the future to a course of action that would produce similar disastrous results. In 1850 , the population of the county was 9,$000 ; 63,545,29$ acres of land was entered in the county. The "Des Moines Republic," published by James Baker \& Co., was first issued in July. A daily line of stages commenced running through the county in August. In September there were 1,290 votes cast.

On the $2 \mathrm{~d}$ day of February, 1850 , the citizens of the county held a plank road meeting at Ottumwa. Several prominent gentlemen were in attendance from Burlington, and addressed the meeting. A company was formed, the object of which was to connect Wapello county with Burlington by plank road. The subscription books of the company were opened on the 16th day of February, 1850, by James W. Norris, Uriah Biggs and Dr. A. D. Wood. During the following six days, $\$ 20,000$ was subscribed; and for a considerable length of time much interest was manifested in this enterprise by the people of the county. Gradually, however, as this character of the roads was demonstrated to be impracticable and unprofitable, the enthusiasm died away, and finally the project was entirely abandoned. After the fall of 1851, the subject was very little spoken of, and if at all, only to be condemned, as a character of public improvement the utility of which was extremely questionable. 
In 1851 occurred the great overflow of the valley of the Des Moines. Nearly if not quite all of the bottom lands in this county were completely inundated. The river rose some ten feet higher than ever before known, submerging and destroying farms, carrying away fences, houses, \&c. The rains continued till late in the summer. Very little grain was planted throughout the county, and those who did manage to plant a few acres, were prohilited from cultirating it, owing to the unceasing rains during the spring and summer months. All the towns immediately on the river were overflowed. The water coursed through the main thoroughfares of both Ottumwa and Eddyville, and for a considerable length of time, row boats floated up and down their principal streets, and good sized river steamers might have safely penetrated their second tier of blocks. Such was the flood of 'כ̌1. Within the recollection of the oldest inhabitant it had no equal, and from the traditionary lore of the aborigines we cannot gather an intimation of a similar event; in fact, no traces are discoverable of an overflow of such vast extent having occurred in the last century preceding this of 'כ̆1. The result was disastrous to farms all over the county, and consequently severely felt by all classes of community. The river was navigable and boating continued during the whole of that season; but the facilities thus afforched for transportation was but a poor recompense for the almost total prevention and destruction of crops, the only resource of the people. During the session of the Legislature of 1851, the "New Code" was adopted, and went into operation on the 1st of July of the same year. Wapello county was represented at that session by Hon. $\mathrm{H}$. B. Hendershott in the Senate, and Hons. J. H. Flint and Andrew Majors in the House. By the adoption of this new code of laws, an entire change in the government of counties took place. The County Commissioners' Court, consisting of three men chosen annually, and which had existed from the first organization of the Territory up to this time, was entirely abolished, and a single officer, styled the County Judge, substituted in its stead. This was a very important change. It 
was taking the whole civil government of the county from the hands of three and placing it in that of one individual, and also making him the Judge of Probate. Yet, while this was the case-while the vast importance of this change was ealculated to startle the people and awake their fears and jealousies, and which caused frequent murmurings and ebullitions of discontent throughout other portions of the State -we cannot but admire the patient and willing manner in which the people of this county submitted to the operation of this change, and with the exception of a single instance, the New Code went into operation successfully, and if not with the entire approbation of the people, yet with their entire willingness to submit it to a fair and impartial trial.

The abjects of this history would condemn a discussion by the author of the relative merits of the two systems of county government. It may, however, suffice to state that with eight years' experience of the County Judge system, there are many honest men who seem satisfied of its impracticability, and advocate the re-adoption of the County Commissioners' Court, while there are others who entertain a different opinion, and display considerable zeal and argument in advocating the continuance of the present system.

The last meeting of the Board of Commissioners, (consisting then of Nathaniel Bell, Samuel Gillilánd and Gideon "MYers,) was held on the 29th day of July, 1851. At this meeting all unfinished business was adjusted, and a final settlement was had with their clerk, A. J. Ridenbaugh, and the County Treasurer, Jos. Leighton. These settlements show that the financial affairs of the county at that time were in a very prosperous and healthy condition-comparatively free of debts and a small surplus in the treasury. Mr. Leighton was Treasurer of the county for several years. He was a gentleman of unflinching integrity, and performed the duties of his office with credit to himself and profit to the people. While he was at the head of the fiscal affairs, the books and papers were in an intelligible condition, and the exact state of the county finances could be ascertained and understood at any 
and all times. The Board of Commissioners, after making settlements with these officers, adjourned sine die, and so ended that form of county government.

On the 12th day of August, 1851, Silas Osborn took the oath of office as County Judge; Thos. Given, as County Clerk; James Pumroy, County Treasurer; D. F. Gaylord, Sheriff; Hiram Fredrick, Supervisor of Roads; A. Brown, Coroner; and Joel B. Myers, County Surveyor. And thus the now organization went quietly and peaceably into operation, with the "single exception" above noted. This was the retention by the Probate Judge of the books and papers of that office for some two weeks, refusing in that time to recognize, as his successor, the newly elected County Judge. After proper reflection, however, his opposition was withdrawn, the contest relinquished, and the books and papers passed over to Judge Osborn.

[To be continued.]

\section{BATTLE AT ATHENS, MISSOURI.}

BY REV. G. o. BEAYMAN, OF CROTON, IOWA.

Athens, Missouri, and Croton, Iowa, are small towns on the Des Moines river, directly opposite to each other.

Difficulties first commenced in Missouri, between the "Secesh" and Union men, on the 5th of July, 1861. The "Secesh" rallied at Kehoka, ten miles south-east of Athens, and commenced depredations on Union families. Home Guards were formed on both sides of the line, for the protection of Union people in Iowa and Missouri. Other preparations were made especially in Missouri, back from the river, some fifteen or twenty miles, where considerable depredations had been committed by the "Secesh;" and several little fights occurred, from the 5 th to the 30 th of July, at Luray, Etna, Edina and Memphis, Mo., in which the Union men were always vietorious.

On the 1st of August, thirty-five tons of provisions came up on the cars of the Des Moines Valley R. R., for our 
Copyright of Annals of Iowa is the property of State of Iowa, by \& through the State Historical Society of Iowa and its content may not be copied or emailed to multiple sites or posted to a listserv without the copyright holder's express written permission. However, users may print, download, or email articles for individual use. 